TEI
Journal of the Text Encoding Initiative

Issue 9 | September 2016 - December 2017

Selected Papers from the 2014 TEI Conference

\title{
Editorial Introduction to Issue 9 of the Journal of the Text Encoding Initiative
}

\section{Martin Müller}

\section{(2) OpenEdition \\ Journals}

Electronic version

URL: http://journals.openedition.org/jtei/1556

DOI: 10.4000/jtei. 1556

ISSN: 2162-5603

Publisher

TEl Consortium

\section{Electronic reference}

Martin Müller, «Editorial Introduction to Issue 9 of the Journal of the Text Encoding Initiative », Journal of the Text Encoding Initiative [Online], Issue 9 I September 2016 - December 2017, Online since 23 April 2017, connection on 24 September 2020. URL : http://journals.openedition.org/jtei/1556 ; DOI https://doi.org/10.4000/jtei.1556

For this publication a Creative Commons Attribution 4.0 International license has been granted by the author(s) who retain full copyright. 


\title{
Editorial Introduction to Issue 9 of the Journal of the Text Encoding Initiative
}

\author{
Martin Müller
}

1 Earlier versions of the papers in this volume were presented at the 2014 conference at Northwestern University. Its theme, "Decoding the Encoded" was my idea because I had often wondered about the point of very intricate forms of encoding when there were not (or not yet) any ways of relatively easily getting out of an encoded text what someone had put into it, typically at a great cost of time and effort. Later I took part in TEI Board meetings where we spent a lot of time weighing the pros and cons of this or that tag line for the next conference.

2 The papers in this volume are representative of the conference in that with one exception they do not really address problems of decoding the encoded. For that matter, the papers at other TEI conferences I have gone to also did not have a whole lot to do with the theme of the year. From which a reasonable person might conclude that worrying about themes does not take you very far. People will do what they feel like doing, and if a paper is interesting, the reviewers are unlikely to reject it as out of scope, especially not in the context of a far-flung but small and close-knit community like the TEI. 
That said, the papers in this volume are interesting. Stadler, Illetscko, and Seifert advance the case for correspondence, a curious stepchild of the TEI. The TEI is not a set of rules for the encoding of literature, but literature has a privileged position, and there are special chapters for verse and drama. Correspondence specific elements are found here and there in the Guidelines, but correspondence is arguably so fundamental a genre of writing that it deserves explicit recognition.

4 A version of Pilate's question "What is truth" shapes "Challenging the Myth of Presentation in Digital Editions" (Turska, Cummings, Rahtz). Where is the "real" in a digital edition? Is it what it looks like on a page and all the technical stuff is just an incomprehensible way of getting there? That is the modal English professor's view of his edition. Or is it the encoding that could support quite different presentations? The authors offer a Processing Model as a bridge between these conflicting views. On a practical level it is a standardizing move that helps reduce costs. At a theoretical level it carries the promise of making the English professor and the XML geek understand a little better what the other is up to.

5 "Formal Ontologies, Linked Data, and TEI Semantics" (Ciotti, Tomasi) reminds me of two different forms of aphasia. Damage to "Broca's area" in the brain leads to a loss of syntactic competence, while damage to "Wernicke's area" leads to babble that is syntactically competent but utterly lacking in meaning. A TEI text reduced to its Xpaths will occasionally give you an idea of what the text is about, but mainly it is what the speech pathologists would call "fluent aphasia." Ontologies and the Semantic Web in their pathological form (Casaubon in Middlemarch) are more like damage to Broca's era. Ordinary humans do quite well at bringing meaning and syntax together. Whether you can fill the empty syntax of a TEI schema with the meaning of an ontology is a tricky question. I confess to some skepticism but salute the effort to square that circle.

6 "Materiality of TEI Encoding and Decoding: an Analysis of the Western European Union Archives on Armament Policy" (Armaselu, Martins, Jones) is an excellent guided tour of what it takes to move documents from the era of the manual typewriter through OCR, TEI encoding, linguistic annotation to a subsequent decoding with the help of sophisticated linguistic analysis tools.

$7 \quad$ The final paper takes us from the Cold War period to a much earlier world: the objects that once were considered worth collecting, were held in the treasure rooms of the rich or powerful, and now live in public museums if they survived at all. Many of them did not but sometimes their traces are found in contemporary descriptions. It is one thing to describe an object. It is another to describe a 
description of a lost object. How do you do this in TEI? That is the question Brent Nelson addresses in "Curating Object-Oriented Collections Using the TEI." That is a very technical question, but the lost objects tell touching stories, as in the case of a description of "a cravat, a shass or girdle, and small pair of gaiters of curious work" in the catalogue prepared by a seventeenth century English clergyman who got it as a present from a London merchant, who had been one among 162 slaves whose release the clergyman negotiated on behalf of Charles II.

\section{AUTHOR}

\section{MARTIN MÜLLER}

